upon-the one is, constantly to associate in the student's mind the practical inportance of the anatomical knowledge he is acyuiring, by referring to the surgical operations in each region, and giving a clear but brief description of their mode of performance, and the dangers or errors to be avoided. We do not always agree with Mr. Wilson as to the best mode of performing these operations, but the principle that bas guided him in thus placing the ultimate object of interest, the surgery, in juxta-position and direct relation with the more dry details of anatomy, is good, and has been carried out in a manner which cannot fail to prove nseful to the student. The work is well adapted for the guidance and instruction of the anatomical student; nor ought we, in summing up its merits, to forget the diagrams, which are valuable additions to the various other means resorted to, in the endeavour to fix the most important parts clearly in the mind's eye; they are both superior in design and execution to those which have bitherto been introduced into class-books. It remains only to add, that after careful examiuation we have no hesitation in recommending this work to the notice of those for whom it has been expressly written, the students, as a guide possessing very superior claims, well calculated to facilitate their studies, and render their labour less irksome, by con. stantly keeping before them defined objects of interest.

\section{COOPER AND MR. FAGAN.}

To the Editor of The Lancet.

Sir:-At your request 1 beg to place befure the readers of THE LANCET a statement of the fucts connected with the publication of the case of John Fagan, who was lately a patient in University College Hospital. The case in question was received from the gentleman who usually furnishes reports to THE LANCFt from that hospital, and the heading which has excited the ire of Mr. Samuel Cooper, was aflixed by me, as subeditor of The Lancer, while the article was passing through the press. On reflecting on the correctness of that heading, I see nothing in it which is not consistent with probability. The patient himself states that for the last eight years Mr. Cooper was in the habit of passing bougies into his bladder. An impression remains on the mind of every one who has read the casp, that Mr. Samuel Cooper was the person alluded to in the expression "Oh, Sir, Mr. Cooper pnt that in ;" and $I$ vaturally drew the same inference, the more readily that I knew of no one who was more likely to have "put that in" than the senior surgeon of the hospital. As to the charges of "interpolation," "calumnies," Sc. in the report, I have simply to remark that such allegations are not ouly false, but made by persons wbo must have known them to be untrue. I remain, Sir,jour obedient servant,

49, Essex-street, Strand,

$$
\text { P. Hexis Green. }
$$

May 26, 1839.

\section{LETTER FROM MR. HARRISON}

$$
\text { ON AN }
$$

\section{INVESTIGATION AT THE WESTMINSTER} HOSPITAL.

\section{To the Editor of THE LANCET.}

SrR:-Observing in your Number of Saturday last a report (?) of the proceedings which took place in the Bonrd.room of the Westminster Hospital, on the 30th of April, I beg leave, through the same mediun, to assert unreservedly that the motion I then submitted to the Board of that charity was in nowise like to the one put into my mouth by the governor-reporter, whom I therefore accuse of perverting the truth. $t^{*} * *$

Having now made the assertion, I shall prove it, and without entering into further discussion, merely refute the report (?) of the writer.

\section{Reporter's version of my Motion.}

"That an inquiry be made into the ccnduct of Mr. Hale Thomson, the assistantsurgeon, for tapping a hydrocele in a patient whose testis was affected with funguid dis. ease."

True Motion, as copied from the Minutes of the Bourd, April 23rd.

"That at the uext meeting (which was the 30th) inquiry be made whether any consultation was held previons to the operation on John Dauzi, who died on the 14th inst., and what the nature of the disease uas calling for the operation."

Now, any impartial reader will immediately perceive the immense diflerence between the two motions. In the true one the conduct of Mr. Hale Thomson is not even alluded to, nor does it state that he tapped a hydrocele; for the words of my motion expressly ask the nature of the disease, which appeared essential, as on the book of the hospital the patient was described to bave been admitted for a "Fungoid Discase of the Testicle;" and when I Leard that a

+ As the name of the reporter was not attached to the communication in question, we object to publish the guess and allusions of Mr. Harrison, though we readily incert his correction of the misstatement.-Ev. L. 